\title{
Contractile responses of human thyroid arteries to vasopressin
}

\author{
José M. Vila ${ }^{\mathrm{a}, \mathrm{c}}$, Martín Aldasoro a,c ${ }^{\mathrm{a}}$, Gloria Segarra ${ }^{\mathrm{a}, \mathrm{c}}$, Juan B. Martínez-León ${ }^{\mathrm{b}}$, María Dolores Mauricio ${ }^{\mathrm{a}, \mathrm{c}}$, \\ Salvador Lluch ${ }^{\mathrm{a}, \mathrm{c}}$, Pascual Medina ${ }^{\mathrm{a}, \mathrm{c}, *}$ \\ a Departamento de Fisiología, Universidad de Valencia, 46010 Valencia, Spain \\ b Servicio de Cirugía Cardiaca, Hospital General de Valencia, 46014 Valencia, Spain \\ c Instituto de Investigación Sanitaria INCLIVA, Hospital Clínico Universitario, 46010 Valencia, Spain
}

\section{A R T I C L E I N F O}

Article history:

Received 28 May 2013

Accepted 20 August 2013

\section{Keywords:}

Endothelium

Human thyroid artery

Nitric oxide

Vasopressin $\mathrm{V}_{1}$-receptor

\begin{abstract}
A B S T R A C T
Aims: In the present study we investigated the intervention of nitric oxide and prostacyclin in the responses to vasopressin of isolated thyroid arteries obtained from multi-organ donors.

Main methods: Paired artery rings from glandular branches of the superior thyroid artery, one normal and the other deendothelised, were mounted in organ baths for isometric recording of tension. Concentrationresponse curves to vasopressin were determined in the absence and in the presence of either the vasopressin $\mathrm{V}_{1}$ receptor antagonist $\mathrm{d}\left(\mathrm{CH}_{2}\right)_{5} \operatorname{Tyr}(\mathrm{Me}) \mathrm{AVP}\left(10^{-8} \mathrm{M}\right)$, the nitric oxide synthase inhibitor $\mathrm{N}^{\mathrm{G}}$-monomethyl-Larginine (L-NMMA, $\left.10^{-4} \mathrm{M}\right)$, or the inhibitor of prostaglandins indomethacin $\left(10^{-6} \mathrm{M}\right)$.

Key findings: In artery rings under resting tension, vasopressin produced concentration-dependent, endotheliumindependent contractions. The vasopressin $\mathrm{V}_{1}$ receptor antagonist $\mathrm{d}\left(\mathrm{CH}_{2}\right)_{5} \operatorname{Tyr}(\mathrm{Me}) \mathrm{AVP}\left(10^{-8} \mathrm{M}\right)$ displaced the control curve to vasopressin 19 -fold to the right in a parallel manner. The contractile response to vasopressin was unaffected by L-NMMA or by indomethacin.

Significance: Vasopressin causes constriction of human thyroid arteries by stimulation of $\mathrm{V}_{1}$ vasopressin receptors located on smooth muscle cells. These effects are not linked to the presence of an intact endothelium or to the release of nitric oxide or prostaglandins. The constriction of thyroid arteries may be particularly relevant in certain pathophysiological circumstances in which vasopressin is released in amounts that could interfere with the blood supply to the thyroid gland.
\end{abstract}

(c) 2013 Elsevier Inc. All rights reserved.

\section{Introduction}

Vasopressin is a neuropeptide that promotes reabsorption of water in renal tubular cells through vasopressin- $\mathrm{V}_{2}$ receptors and produces contraction of vascular smooth muscle through vasopressin$\mathrm{V}_{1}$ receptors (Michell et al., 1979; Penit et al., 1983; Barrett et al., 2007). With regard to human vessels, vasopressin causes powerful $V_{1}$ receptor-mediated constriction in isolated mesenteric (Ohlstein and Berkowitz, 1986; Martínez et al., 1994b), cerebral (Lluch and Gómez, 1987; White and Robertson, 1987) and renal (Medina et al., 1996b) arteries. This effect is endothelium-independent and due to direct stimulation of receptors located on smooth muscle cells (Martín de Aguilera et al., 1990; Martínez et al., 1994a, b). Both hyperthyroidism and hypothyroidism are associated with marked effects on the cardiovascular system including changes in cardiac output, blood pressure, and systemic vascular resistance (Klein and Ojamaa, 2001). On the other

\footnotetext{
* Corresponding author at: Departamento de Fisiología, Facultad de Medicina y Odontología, Universidad de Valencia, Av. Blasco Ibañez 15, 46010 Valencia, Spain. Tel.: + 34 963864983; fax: + 34963864642 .

E-mail address: Pascual.Medina@uv.es (P. Medina).
}

hand, impaired thyroid function is accompanied by changes in plasma vasopressin levels (Arnaout et al., 1992; Marcisz et al., 2001) that might be responsible for constriction of thyroid vessels. The effects of vasopressin in these arteries are not fully known. Such data might be of pathophysiological significance in those states characterised by increased plasma vasopressin levels, such as haemorrhagic and septic shock (Landry et al., 1997; Tsuneyoshi et al., 2003) and in some patients with congestive heart failure (Rouleau et al., 1994; Goldsmith and Gheorghiade, 2005). Studies from our laboratory have shown that in human thyroid arteries from multiorgan donors the endothelium modulates responses to acetylcholine and noradrenaline through the release of nitric oxide (NO), an endothelium-derived relaxing factor (Torondel et al., 2004; Ortega et al., 2005). Moreover, NO production is decreased in hyperthyroid patients when compared with control subjects (Hermenegildo et al., 2002). These results strongly suggest that endothelial NO might play a key role in the responsiveness of thyroid arteries to specific pharmacological interventions. Accordingly, the aim of the present study was to determine the effects of vasopressin in human thyroid arteries obtained from multiorgan donors. Observations were made in the presence and in the absence of endothelium and after exposure to $\mathrm{N}^{\mathrm{G}}$-monomethyl-L-arginine (L-NMMA), an inhibitor of NO synthase, or the vasopressin $\mathrm{V}_{1}$ receptor antagonist $\mathrm{d}\left(\mathrm{CH}_{2}\right)_{5} \operatorname{Tyr}(\mathrm{Me})$ AVP. 


\section{Material and methods}

\section{Subjects}

Glandular branches of the superior thyroid artery were obtained from 12 multiorgan donors during procurement of organs for transplantation ( 8 men and 4 women; age range: 22-65 years; cause of death: 7 head trauma, 2 intracranial haemorrhage, 3 myocardial infarction). The study was approved by the ethical committee of our institution. The vessels were immediately placed in a Petri dish containing refrigerated $\left(4{ }^{\circ} \mathrm{C}\right)$ modified Krebs-Henseleit solution of the following $\mathrm{mM}$ composition: $\mathrm{NaCl}, 115 ; \mathrm{KCl}, 4.6 ; \mathrm{KH}_{2} \mathrm{PO}_{4}, 1.2 ; \mathrm{MgCl}_{2} \cdot 6 \mathrm{H}_{2} \mathrm{O}, 1.2 ; \mathrm{CaCl}_{2}, 2.5$; $\mathrm{NaHCO}_{3}, 25$; glucose 11.1 and disodium EDTA, 0.01 .

\section{In vitro experiments}

Experiments started within $2 \mathrm{~h}$, or not more than $8 \mathrm{~h}$ after organs were removed. When used within 2 to $8 \mathrm{~h}$, the vessels were stored in the $4{ }^{\circ} \mathrm{C}$ modified Krebs-Henseleit solution, which was found not to alter either the endothelium-dependent relaxation to acetylcholine or the contractile response to $\mathrm{KCl}$ or vasopressin. Arteries were cleaned of connective tissue and cut into rings ( $3 \mathrm{~mm}$ in length, 1 to $1.5 \mathrm{~mm}$ outer diameter) under a dissecting microscope. In some experiments, the endothelium was removed mechanically by inserting a roughened stainless-steel wire into the lumen and gently rolling the vessel ring on wet filter paper. Each ring was suspended between two stainlesssteel L-shaped pins in 4-mL organ baths containing modified KrebsHenseleit solution. The solution was equilibrated with 95\% oxygen and $5 \%$ carbon dioxide to give a pH from 7.3 to 7.4 and maintained at $37{ }^{\circ} \mathrm{C}$ with a circulating water jacket and a heat pump. One pin was fixed to the organ bath wall and the other was connected to a strain gauge (model FT03; Grass Instrument Division of Astro-Med Inc., West Warwick, RI). Changes in isometric force were recorded on a Macintosh computer (Apple Computer, Cupertino, CA, USA) by use of Chart version 3.4/s software and a MacLab/8e data acquisition system (ADInstruments, Mountain View, CA, USA). To establish the resting tension for maximal force development, we performed a series of preliminary experiments on thyroid artery rings which were exposed repeatedly to $100 \mathrm{mM} \mathrm{KCl}$. Basal tension was increased gradually until contractions were maximal. The optimal resting tension was $10 \mathrm{mN}$. The rings were allowed to attain a steady level of tension during a 2to 3-hour accommodation period before testing. The contractile response to $100 \mathrm{mM} \mathrm{KCl}$ was similar in intact and denuded arteries $(24.7 \pm 4.8$ versus $23.9 \pm 4.1 \mathrm{mN} ; n=8, \mathrm{P}>0.05)$.

Functional integrity of the endothelium was confirmed routinely by the presence of relaxation induced by acetylcholine $\left(10^{-7}\right.$ to $\left.10^{-6} \mathrm{M}\right)$ during contraction obtained with noradrenaline $\left(10^{-6}\right.$ to $\left.3 \times 10^{-6} \mathrm{M}\right)$. Arteries in which the acetylcholine reversed the noradrenalineinduced tone by more than $70 \%$ were designated as endothelium intact and arteries in which acetylcholine caused less than $15 \%$ relaxation were designated as denuded.

Concentration-response curves to vasopressin were determined in a cumulative manner under the following conditions: (1) in the absence of inhibitors (control response); (2) in the presence of the $V_{1}$-receptor antagonist 1-( $\beta$-mercapto- $\beta, \beta$-cyclopentamethylene-propionic acid) 2-(O-methyl)-tyrosine, 8-arginine) vasopressin $\left(\mathrm{d}\left(\mathrm{CH}_{2}\right)_{5} \mathrm{Tyr}(\mathrm{Me}) \mathrm{AVP}\right.$, $\left.10^{-8} \mathrm{M}\right) ;(3)$ in the presence of L-NMMA $\left(10^{-4} \mathrm{M}\right)$ to inhibit NO synthase; and (4) in the presence of indomethacin $\left(10^{-6} \mathrm{M}\right)$ to inhibit the production of $\mathrm{PGI}_{2}$. Control (in the absence of inhibitors) and experimental (after incubation for $20 \mathrm{~min}$ with inhibitors) responses were obtained from separate artery rings.

\section{Chemicals}

All substances were purchased from Sigma Chemical Co. (St. Louis, MO, USA).

\section{Data analysis}

All values are expressed as means \pm SEM. Contractile effects were expressed as a percentage of the response to $\mathrm{KCl}(100 \mathrm{mM})$. $\mathrm{EC}_{50}$ values (concentration of agonist producing half-maximum effect) were expressed as $\mathrm{pD}_{2}\left(-\log \mathrm{EC}_{50}\right)$. The maximum contractions and $\mathrm{pD}_{2}$ values were compared by one-way analysis of variance (ANOVA) with the Bonferroni test as post hoc test. $n$ values are presented as the number of donors. Statistical significance was accepted at $\mathrm{P}<0.05$.

\section{Results}

$\mathrm{KCl}(100 \mathrm{mM})$ produced a sustained contraction with a maximal effect of $24.3 \pm 3.1 \mathrm{mN}$ (Fig. 1). In precontracted arteries with noradrenaline $\left(10^{-6} \mathrm{M}\right)$, acetylcholine $\left(10^{-6} \mathrm{M}\right)$ caused relaxation in arteries with an intact endothelium, but was abolished in endothelium-denuded rings (Fig. 1). Cumulative application of vasopressin produced a constrictor response that was concentration-dependent (Fig. 1). The maximum tension developed as well as the $\mathrm{pD}_{2}$ were similar $(\mathrm{P}>0.05)$ in arterial segments with and without endothelium (Fig. 1 and Table 1). The presence of the vasopressin $\mathrm{V}_{1}$-selective receptor antagonist $\mathrm{d}\left(\mathrm{CH}_{2}\right)_{5} \mathrm{Tyr}(\mathrm{Me})$ AVP $\left(10^{-8} \mathrm{M}\right)$ in the organ bath shifted the concentration-response curve to vasopressin 19 -fold $(\mathrm{P}<0.05)$ to the right in a parallel manner, but differences in the maximum tensions developed were not significant $(\mathrm{P}>0.05)$ (Fig. 1D and Table 1).

The presence of L-NMMA $\left(10^{-4} \mathrm{M}\right)$ did not change significantly $(P>0.05)$ the concentration-response curve for vasopressin (Fig. 2 and Table 1). However, L-NMMA decreased acetylcholine-induced relaxation in artery rings precontracted with noradrenaline $\left(10^{-6}-3 \times 10^{-6} \mathrm{M}\right)$, thus showing the ability of these vessels to display NO-mediated relaxation (Fig. 2B). Arteries exposed to indomethacin $\left(10^{-6} \mathrm{M}\right)$ did not show significant changes in the contractile response to vasopressin (Fig. 2 and Table 1).

\section{Discussion}

Our results indicate that vasopressin is a potent agonist for the contraction of thyroid vascular smooth muscle through activation of specific $V_{1}$-vasopressin receptors. The maximum tensions with respect to $\mathrm{KCl}$ response and sensitivity (in terms of $\mathrm{pD}_{2}$ values) attained with vasopressin in thyroid arteries are within the range of values obtained in other human arteries (Medina et al., 1997; Aldasoro et al., 2008) but higher than the corresponding values in human saphenous vein (Aldasoro et al., 1997; Medina et al., 1997).

The functional properties of the endothelium-NO system of human thyroid arteries remain largely unexplored. NO synthase, the enzyme responsible for the formation of NO (Palmer et al., 1988 ) is present in the thyroid follicular cells and in endothelial cells of the human thyroid gland (Colin et al., 1997), and human thyrocites produce the endogenous NO synthase inhibitor asymmetric dimethylarginine (ADMA) (Colin et al., 1995; Millatt et al., 2000). In addition, NO modulates the response of human thyroid arteries to acetylcholine and noradrenaline (Torondel et al., 2004). Previously, we have demonstrated in human thyroid arteries that treatment with L-NMMA reduces the endothelium-dependent relaxation to acetylcholine. The NO component, sensitive to L-NMMA, accounted for approximately $20 \%$ of the maximum relaxation to acetylcholine. The NOindependent relaxation results from the release by acetylcholine of endothelium-dependent hyperpolarizing factor (EDHF). The EDHF component involves activation of $\mathrm{Ca}^{2+}$-dependent $\mathrm{K}^{+}$channels, sensitive to charybdotoxin and apamin (Torondel et al., 2004).

All these results are consistent with a role for NO in responsiveness of thyroid arteries. However, the intervention of NO seems to be restricted to specific pharmacological receptors. Indeed the present experiments show that the vasopressin-induced contraction is not linked to the presence of an intact endothelium. The evidence for this 
A With endothelium

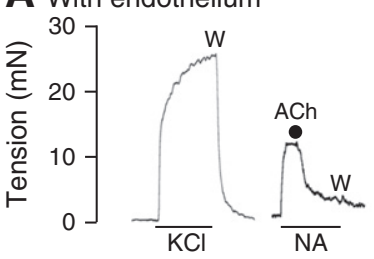

B Without endothelium

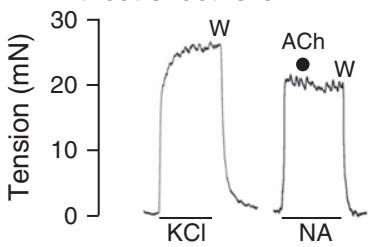

C With endothelium

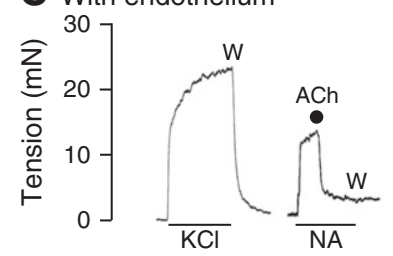

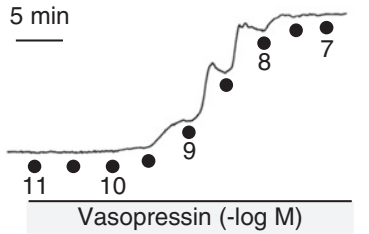
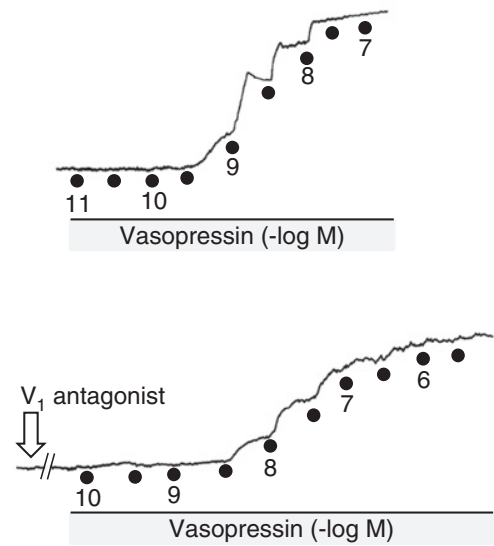
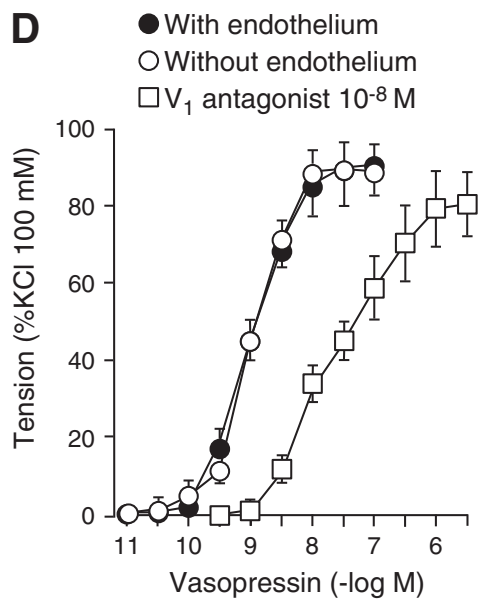

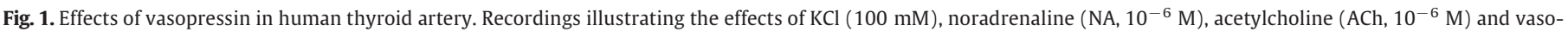

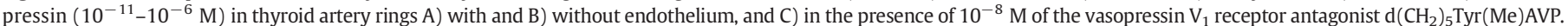

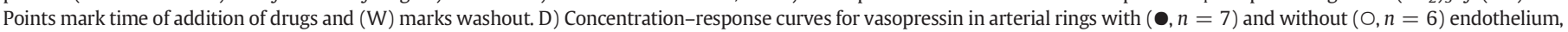

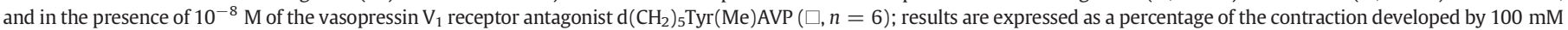
$\mathrm{KCl}$. Values are means $\pm \mathrm{SEM}$.

is that the contraction was similar in intact and endothelium-denuded arteries. In agreement with the present results, previous experiments have shown that vasopressin causes endothelium-independent contraction in several human arteries (Martínez et al., 1994a, b; Medina et al., 1996b; Segarra et al., 1998). Furthermore, the contraction does not involve the intervention of the L-arginine-NO pathway because L-NMMA, a selective inhibitor of NO synthase, did not modify the vasopressin-induced contraction. The present results are consistent with previous data showing that NO synthase inhibition does not affect the vasopressin-induced contractions in human arteries (Medina et al., 1996a,b). However, in vitro and in vivo experiments indicate that a considerable regional heterogeneity exists in the reactivity of blood vessels to vasopressin. In isolated rabbit saphenous, coronary and renal arteries, and to a minor degree in basilar arteries, the endothelium has an inhibitory effect on the vasoconstriction induced by vasopressin mediated by the release of NO (García-Villalón et al., 1996).

As vasopressin has been reported to induce vasodilating prostaglandin synthesis via a $V_{1}$ receptor-dependent pathway (Nakatani et al.,

Table 1

$\mathrm{pD}_{2}$ values and maximum contractions (Emax) to vasopressin in the different experimental conditions in segments of human thyroid arteries.

\begin{tabular}{lll}
\hline Artery rings & $\mathrm{pD}_{2}$ & Emax (\%) \\
\hline With endothelium $(n=7)$ & $8.97 \pm 0.25$ & $88 \pm 6$ \\
Without endothelium $(n=6)$ & $8.93 \pm 0.24$ & $90 \pm 5$ \\
L-NMMA $\left(10^{-4} \mathrm{M}\right)(n=5)$ & $9.00 \pm 0.19$ & $95 \pm 7$ \\
Indomethacin $\left(10^{-6} \mathrm{M}\right)(n=5)$ & $8.87 \pm 0.21$ & $78 \pm 5$ \\
$\mathrm{~d}\left(\mathrm{CH}_{2}\right)_{5} \operatorname{Tyr}(\mathrm{Me}) \mathrm{AVP}\left(10^{-8} \mathrm{M}\right)(n=6)$ & $7.69 \pm 0.33^{*}$ & $77 \pm 7$ \\
\hline
\end{tabular}

$n=$ number of donors; $\mathrm{pD}_{2}=$ negative logarithm of molar concentration required to produce half-maximum response. Emax is expressed as a percentage of responses to $100 \mathrm{mM} \mathrm{KCl}$. Values are mean \pm SEM.

$* \mathrm{P}<0.05$ vs artery segments with endothelium.
2007) it might be expected that cyclooxygenase inhibitors can modulate the responses to vasopressin. Indomethacin potentiates the vasopressininduced contraction in human mesenteric (Martínez et al., 1994b) and renal (Medina et al., 1996b) arteries with or without endothelium, thus suggesting that relaxant prostaglandins, derived mainly from smooth muscle cells, attenuate the $\mathrm{V}_{1}$-mediated contractile effect of vasopressin. However, contractile responses of human thyroid artery to vasopressin were unaffected by cyclooxygenase inhibition, thus suggesting that in this vessel, vasopressin does not stimulate the release of prostanoids. A common finding in the vascular effects of vasopressin is the heterogeneity of responsiveness, depending on regional and species differences (García-Villalón et al., 1996). Therefore, it is likely that the contractile effects of vasopressin in thyroid arteries are due to direct stimulation of specific receptors located on smooth muscle cells.

$\mathrm{d}\left(\mathrm{CH}_{2}\right)_{5} \operatorname{Tyr}(\mathrm{Me}) \mathrm{AVP}$ has been reported to be a potent inhibitor of the contractile response to vasopressin in human arteries (Martínez et al., 1994a,b; Medina et al., 1996b; Segarra et al., 1998). Furthermore, this compound does not interfere with the vasoconstrictor response to angiotensin II, noradrenaline or $\mathrm{KCl}$ (Ohlstein and Berkowitz, 1986; Fox et al., 1987). The present results show that $\mathrm{d}\left(\mathrm{CH}_{2}\right)_{5} \mathrm{Tyr}(\mathrm{Me}) \mathrm{AVP}$ is an effective antagonist of the response to vasopressin in human thyroid arteries. At $10^{-8} \mathrm{M}$, the antagonist produced a 19-fold shift to the right of the control concentration-response curve to vasopressin, presumably due to a competitive agonist-antagonist interaction.

Plasma levels of vasopressin increase in response to stimuli such as increased plasma osmolality (Mason, 1980), dehydration, hypotension (Sorenson and Hammer, 1985), exercise (Melin et al., 1980), increased angiotensin II levels (Bonjour and Malvin, 1970), and sympathetic activation (Leng et al., 1999) and in different pathophysiological settings such as, haemorrhage (Fujisawa et al., 1994), and congestive heart failure (Preibisz et al., 1983). In addition, vasopressin may modify the effects of other vasoactive substances that are found in plasma or released from perivascular nerve endings. Several studies have reported 

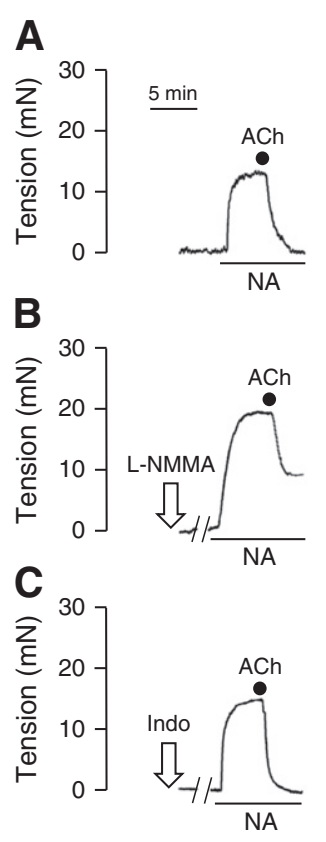
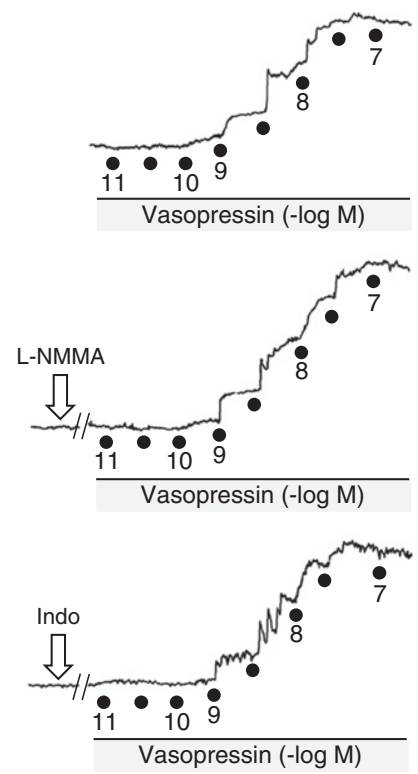

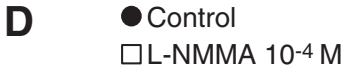

$\triangle$ Indomethacin $10^{-6} \mathrm{M}$

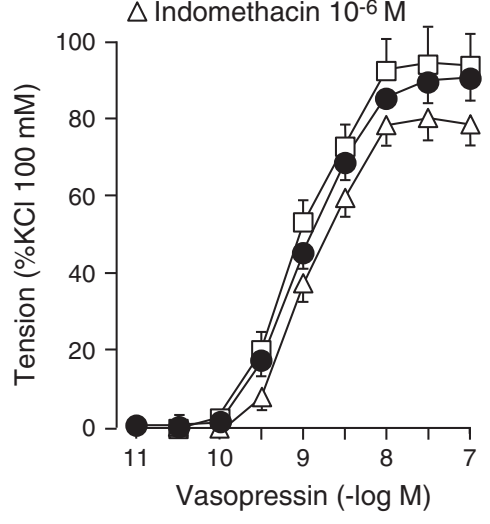

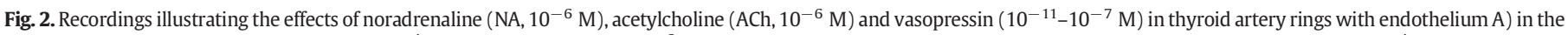

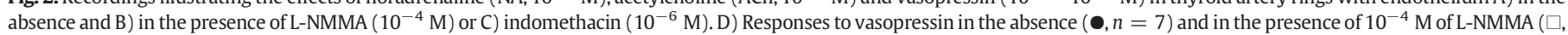
$n=5$ ) or $10^{-6} \mathrm{M}$ of indomethacin $(\Delta, n=5)$; results are expressed as a percentage of the contraction developed by $100 \mathrm{mM} \mathrm{KCl}$. Values are means $\pm \mathrm{SEM}$.

a significant augmentation by vasopressin of the vasoconstricting action of catecholamines (Medina et al., 1997; Segarra et al., 1998). Consequently, the vascular effects of vasopressin on thyroid artery may be particularly relevant in those states characterised by increased vasopressin plasma levels as well as in those clinical situations, such as asystolic cardiac arrest, refractory arterial hypotension during anaesthesia, septic shock, or oesophageal variceal haemorrhage, in which vasopressin and synthetic vasopressin receptor agonists are used as a therapeutic tool (Treschan and Peters, 2006). Under these conditions the contractile response of the thyroid artery induced by vasopressin may reduce thyroid blood flow and thyroid hormone release. Interestingly, along with increased levels of vasopressin, low thyroid hormone circulating levels have been described in patients with heart failure (Hamilton et al., 1990) and are associated with poor prognosis (lervasi et al., 2003). These findings suggest a potential link between the vasoconstrictive effects of vasopressin on thyroid arteries and low plasmatic thyroid hormone concentrations associated with unfavourable outcomes of these patients. Nevertheless, we cannot deduce from our observations whether disease-related increases in plasma vasopressin would reduce thyroid blood flow enough to significantly affect thyroid function. Future studies will therefore be needed to define the role of vasopressin in the regulation of thyroid blood flow.

In view of the specificity and potency of the vasopressin $V_{1}$ receptor antagonist $\mathrm{d}\left(\mathrm{CH}_{2}\right)_{5} \mathrm{Tyr}(\mathrm{Me}) \mathrm{AVP}$, it seems appropriate to consider the use of vasopressin receptor antagonists as a potentially beneficial therapeutic approach in circumstances in which vasopressin plasma concentrations are markedly raised (e.g. congestive heart failure). Indeed, several vasopressin antagonists, orally active in humans, are presently undergoing clinical development (Arai et al., 2007).

\section{Conclusions}

Our study shows that vasopressin exerts a powerful constrictor action on isolated human thyroid arteries by direct stimulation of $\mathrm{V}_{1}$-vasopressin receptors located on smooth muscle cells. It appears that in these arteries the contractile response to vasopressin is not modulated by the NO and cyclooxygenase pathways.

\section{Conflict of interest statement}

The authors declared no conflict of interest.

\section{Acknowledgements}

This work was supported by the Ministerio de Ciencia e Innovación, Universitat de Valencia (grant UV-INV-AE13-141529) and Conselleria de Sanidad de la Generalitat Valenciana.

\section{References}

Aldasoro M, Medina P, Vila JM, Otero E, Martínez-León JB, Lluch S. Endothelium-dependent relaxation of human saphenous veins in response to vasopressin and desmopressin. J Vasc Surg 1997;25:696-703.

Aldasoro M, Mauricio MD, Serna E, Cortina B, Segarra G, Medina P, et al. Effects of aspirin, nimesulide, and SC-560 on vasopressin-induced contraction of human gastroepiploic artery and saphenous vein. Crit Care Med 2008;36:193-7.

Arai Y, Fujimori A, Sudoh K, Sasamata M. Vasopressin receptor antagonists: potential indications and clinical results. Curr Opin Pharmacol 2007;7:124-9.

Arnaout MA, Awidi AS, el-Najdawi AM, Khateeb MS, Ajlouni KM. Arginine-vasopressin and endothelium-associated proteins in thyroid disease. Acta Endocrinol (Copenh) 1992;126:399-403.

Barrett LK, Singer M, Clapp LH. Vasopressin: mechanisms of action on the vasculature in health and in septic shock. Crit Care Med 2007;35:33-40.

Bonjour JP, Malvin RL. Stimulation of ADH release by the renin-angiotensin system. Am J Physiol 1970;218:1555-9.

Colin IM, Nava E, Toussaint D, Maiter DM, vanDenhove MF, Luscher TF, et al. Expression of nitric oxide synthase isoforms in the thyroid gland: evidence for a role of nitric oxide in vascular control during goiter formation. Endocrinology 1995;136:5283-90.

Colin IM, Kopp P, Zbaren J, Haberli A, Grizzle WE, Jameson JL. Expression of nitric oxide synthase III in human thyroid follicular cells: evidence for increased expression in hyperthyroidism. Eur J Endocrinol 1997;136:649-55.

Fox AW, Karapanos G, Mitch WE. Noncompetitive blockade of vasopressin-1 receptors in rat tail artery. J Pharmacol Exp Ther 1987;243:598-602.

Fujisawa Y, Miyatake A, Hayashida Y, Aki Y, Kimura S, Tamaki T, et al. Role of vasopressin on cardiovascular changes during hemorrhage in conscious rats. Am J Physiol 1994;267:H1713-8.

García-Villalón AL, García JL, Fernandez N, Monge L, Gomez B, Dieguez G. Regional differences in the arterial response to vasopressin: role of endothelial nitric oxide. $\mathrm{Br} \mathrm{J}$ Pharmacol 1996;118:1848-54. 
Goldsmith SR, Gheorghiade M. Vasopressin antagonism in heart failure. J Am Coll Cardiol 2005;46:1785-91.

Hamilton MA, Stevenson LW, Luu M, Walden JA. Altered thyroid hormone metabolism in advanced heart failure. J Am Coll Cardiol 1990;16:91-5.

Hermenegildo C, Medina P, Peiro M, Segarra G, Vila JM, Ortega J, et al. Plasma concentration of asymmetric dimethylarginine, an endogenous inhibitor of nitric oxide synthase, is elevated in hyperthyroid patients. J Clin Endocrinol Metab 2002;87: 5636-40.

Iervasi G, Pingitore A, Landi P, Raciti M, Ripoli A, Scarlattini M, et al. Low-T3 syndrome: a strong prognostic predictor of death in patients with heart disease. Circulation 2003;107:708-13.

Klein I, Ojamaa K. Thyroid hormone and the cardiovascular system. N Engl J Med 2001;344:501-9.

Landry DW, Levin HR, Gallant EM, Seo S, D'Alessandro D, Oz MC, et al. Vasopressin pressor hypersensitivity in vasodilatory septic shock. Crit Care Med 1997;25:1279-82.

Leng G, Brown CH, Russell JA. Physiological pathways regulating the activity of magnocellular neurosecretory cells. Prog Neurobiol 1999;57:625-55.

Lluch S, Gómez B. Vasopressin and the cerebral circulation. In: Edvinsson L, McCulloch J, editors. Peptidergic mechanisms in the cerebral circulation. Physiology and pharmacology of vascular neuroeffector systemsWeinheim: Verlagsgesellschaft; 1987. p. $152-65$.

Marcisz C, Jonderko G, Kucharz EJ. Influence of short-time application of a low sodium diet on blood pressure in patients with hyperthyroidism or hypothyroidism during therapy. Am J Hypertens 2001;14:995-1002.

Martín de Aguilera E, Vila JM, Irurzun A, Martínez MC, Martínez Cuesta MA, Lluch S. Endothelium-independent contractions of human cerebral arteries in response to vasopressin. Stroke 1990;21:1689-93.

Martínez MC, Aldasoro M, Vila JM, Medina P, Lluch S. Responses to vasopressin and desmopressin of human cerebral arteries. J Pharmacol Exp Ther 1994a;270: $622-7$.

Martínez MC, Vila JM, Aldasoro M, Medina P, Flor B, Lluch S. Relaxation of human isolated mesenteric arteries by vasopressin and desmopressin. $\mathrm{Br} \mathrm{J}$ Pharmacol 1994b;113:419-24.

Mason WT. Supraoptic neurones of rat hypothalamus are osmosensitive. Nature 1980;287: $154-7$.

Medina P. Martínez MC, Aldasoro M, Vila JM, Chuan P. Lluch S. Contractile responses of human deferential artery and vas deferens to vasopressin. Eur J Pharmacol 1996a;300:221-5.

Medina P, Vila JM, Martínez MC, Aldasoro M, Chuan P, Lluch S. Effects of vasopressin on human renal arteries. Eur J Clin Invest 1996b;26:966-72.

Medina P, Noguera I, Aldasoro M, Vila JM, Flor B, Lluch S. Enhancement by vasopressin of adrenergic responses in human mesenteric arteries. Am J Physiol 1997;272: H1087-93.
Melin B, Eclache PJ, Geelen G, Annat G, Allevard AM, Jarsaillon E, et al. Plasma AVP, neurophysin, renin activity, and aldosterone during submaximal exercise performed until exhaustion in trained and untrained men. Eur J Appl Physiol 1980;44:141-51.

Michell RM, Kirk CJ, Billah MM. Hormonal stimulation of phosphatidylinositol breakdown, with particular reference to the hepatic effects of vasopressin. Biochem Soc Trans 1979;7:861-5.

Millatt LJ, Johnstone AP, Nussey SS, Whitley GS. Thyrocyte release of asymmetric dimethylarginine does not account for human thyrocyte inhibition of endothelial cell cyclic GMP. Eur J Endocrinol 2000;142:493-9.

Nakatani Y, Chin Y, Hara S, Kudo I. Immediate prostaglandin $E_{2}$ synthesis in rat 3Y1 fibroblasts following vasopressin V1a receptor stimulation. Biochem Biophys Res Commun 2007;354:676-80.

Ohlstein EH, Berkowitz BA. Human vascular vasopressin receptors: analysis with selective vasopressin receptor antagonists. J Pharmacol Exp Ther 1986;239:737-41.

Ortega J, Vila JM, Mauricio MD, Segarra G, Medina P, Martinez-Leon JB, et al. Nitric oxide mediates abnormal responsiveness of thyroid arteries in methimazole-treated patients. Eur J Endocrinol 2005;152:551-6.

Palmer RMJ, Ashton DS, Moncada S. Vascular endothelial cells synthesize nitric oxide from L-arginine. Nature 1988;333:664-6.

Penit J, Faure M, Jard S. Vasopressin and angiotensin II receptors in rat aortic muscle cells in culture. Am J Physiol 1983;244:E72-82.

Preibisz JJ, Sealey JE, Laragh JH, Cody RJ, Weksler BB. Plasma and platelet vasopressin in essential hypertension and congestive heart failure. Hypertension 1983;5: I129-38.

Rouleau JL, Packer M, Moye L, de CJ Bichet D, Klein M, et al. Prognostic value of neurohumoral activation in patients with an acute myocardial infarction: effect of captopril. J Am Coll Cardiol 1994;24:583-91.

Segarra G, Medina P, Domenech C, Vila JM, Martínez-León JB, Aldasoro M, et al. Role of vasopressin on adrenergic neurotransmission in human penile blood vessels. J Pharmacol Exp Ther 1998;286:1315-20.

Sorenson PS, Hammer M. Vasopressin in plasma and ventricular cerebrospinal fluid during dehydration, postural changes and nausea. Am J Physiol 1985;17:R78-83.

Torondel B, Vila JM, Segarra G, Lluch P, Medina P, Martinez-Leon J, et al. Endotheliumdependent responses in human isolated thyroid arteries from donors. J Endocrinol 2004;181:379-84.

Treschan TA, Peters J. The vasopressin system: physiology and clinical strategies. Anesthesiology 2006;105:599-612.

Tsuneyoshi I, Zhang D, Boyle III WA. $\mathrm{Ca}^{2+}$ - and myosin phosphorylation-independent relaxation by halothane in $\mathrm{K}^{+}$-depolarized rat mesenteric arteries. Anesthesiology 2003;99:656-65.

White RP, Robertson JT. Pharmacodynamic evaluation of human cerebral arteries in the genesis of vasospasm. Neurosurgery 1987;21:523-31. 